\title{
Nanoencapsulated Melaleuca alternifolia essential oil exerts anesthetic effects in the brachyuran crab using Neohelice granulata
}

\author{
CARINE F. SOUZA ${ }^{1}$, TÁBATA LIMA ${ }^{2}$, MATHEUS D. BALDISSERA ${ }^{3}$, MÁRCIO A. GEIHS ${ }^{4}$, \\ FÁBIO E. MACIEL ${ }^{2}$, LUIZ E.M. NERY ${ }^{2}$, ROBERTO C.V. SANTOS ${ }^{3}$, RENATA P. RAFFIN ${ }^{5}$, \\ BERTA M. HEINZMANN ${ }^{6}$, BRAULIO O. CARON ${ }^{7}$ and BERNARDO BALDISSEROTTO ${ }^{1}$ \\ ${ }^{1}$ Departamento de Fisiologia e Farmacologia, Universidade Federal de Santa Maria/ \\ UFSM, Avenida Roraima, 1000, 97105-900 Santa Maria, RS, Brazil \\ ${ }^{2}$ Programa de Pós-Graduação em Ciências Fisiológicas - Fisiologia Animal Comparada, Instituto de Ciências \\ Biológicas, Universidade Federal do Rio Grande/FURG, Av. Itália, Km 8, 96201-900 Rio Grande, RS, Brazil \\ ${ }^{3}$ Departamento de Microbiologia e Parasitologia, Universidade Federal de Santa Maria/ \\ UFSM, Avenida Roraima, 1000, 97105-900 Santa Maria, RS, Brazil \\ ${ }^{4}$ Instituto de Oceanografia, Laboratório de Microcontaminantes Orgânicos e Ecotoxicologia, Universidade \\ Federal do Rio Grande/FURG, Av. Itália, Km 8, 96201-900 Rio Grande, RS, Brazil \\ ${ }^{5}$ Laboratório de Nanotecnologia, Centro Universitário Franciscano, Rua dos Andradas, \\ 1460, 97010-491 Santa Maria, RS, Brazil \\ ${ }^{6}$ Departamento de Farmácia Industrial, Universidade Federal de Santa Maria/ \\ UFSM, Avenida Roraima, 1000, 97105-900 Santa Maria, RS, Brazil \\ ${ }^{7}$ Departamento de Agronomia e Ciências Ambientais, Universidade Federal de Santa Maria, \\ Centro de Educação Superior Norte do Rio Grande do Sul, Campus Frederico Westphalen, Linha \\ Sete de Setembro, s/n, BR 386, Km 40, 98400-000 Frederico Westphalen, RS, Brazil \\ Manuscript received on November 17, 2017; accepted for publication on January 25, 2018
}

\begin{abstract}
The aim of this study was to evaluate the efficacy and safety of several anesthetics in the brachyuran crab Neohelice granulata, an emergent experimental model. The essential oils (EOs) of Lippia alba, Aloysia tryphilla, and Melaleuca alternifolia (tea tree oil; TTO), the isolated compounds eugenol, menthol, terpinen-4-ol, and the nanoencapsulated form of TTO, were administered in one or more of the following ways: added to the water (immersion), through an arthrodial membrane (injected), or by oral gavage. Unexpectedly, most EOs did not produce an anesthetic effect after immersion. Only TTO and eugenol induced anesthesia by immersion, with very long induction and recovery times compared to anesthesia of other crustaceans. However, a good anesthetic effect was observed with the injection of terpinen-4-ol and nanoencapsulated TTO in N. granulata; both demonstrated ideal induction and recovery times. These substances appear to be promising anesthetic alternatives for crustaceans.
\end{abstract}

Key words: anesthesia, eugenol, terpinen-4-ol, nanotechnology, invertebrate, tea-tree-oil.

Correspondence to: Carine Souza

E-mail: carinedefs@yahoo.com.br 


\section{INTRODUCTION}

Crustaceans may experience pain and stress in ways that are analogous to those of vertebrates, demonstrating a similar experience in terms of suffering (Elwood and Appel 2009). In this sense, using different noxious stimuli and behavioral responses to indicate pain, study conducted by Barr et al. (2008) demonstrated that crustacean Palaemon elegans presents a physiological stress response analogous to the pain observed in vertebrates, concluding that this specie needs attention during manipulation.

Current methods for stunning, anesthesia, and euthanasia include freezing, direct blunt force in the rostrum, injection of magnesium chloride or potassium chloride, or carbon dioxide $\left(\mathrm{CO}_{2}\right)$ exposure (Cooper 2011). However, these methods are not considered safe or suitable in accordance with the American Veterinary Medical Association (AVMA 2007); thus, alternative methods, such as the use of anesthetics, are required to avoid or minimize the suffering of animals. Moreover, recently it has been shown that the crustacean nervous system is capable of preserving nerve cell communication and rhythmicity even at extremely low temperatures (Marder et al. 2011, Tang et al. 2012). Magnesium chloride and exposure to $\mathrm{CO}_{2}$ are not effective as anesthetics, and $\mathrm{CO}_{2}$ reduces water $\mathrm{pH}$, leading to stress before paralysis and/or death (Fregin and Bickmeyer 2016). This has led us to question how decapod crustaceans can be safely anesthetized before treating them in physiological experiments or carcinoculture.

In fish farming, anesthetics have been successfully used to minimize stress and pain, facilitate handling and transport, and prevent injury (Gunkel et al. 2007, Ross and Ross 2008). Crustaceans can also be anesthetized with synthetic anesthetics, such as tricaine methanesulfonate (MS222), isobutyl alcohol, and intramuscular injections of lidocaine, ketamine, pentobarbital, propofol, tiletamine-zolazepam, or xylazine (Brown et al. 1996, Ferraro and Pressacco 1996, Quesada et al. 2011). However, the use of synthetic anesthetics can be harmful to animals. For example, MS-222 can be toxic and may cause aversive reactions (Yue 2008).

Alternatively, the use of natural products with anesthetic potential, such as clove oil (Eugenia aromatica essential oil), have shown promise, and may offer more security for animals (Morgan et al. 2001). Several studies have demonstrated that clove oil is a popular anesthetic for procedures such as handling and transportation of some aquatic animals (Keene et al. 1998, Griffiths 2000). In addition, clove oil has already been tested for cephalopods (Seol et al. 2007, Gonçalves et al. 2012), amphibians (Hernández et al. 2012), and crustaceans (Keene et al. 1998, Morgan et al. 2001, Bownik 2015, Premarathna et al. 2016). Eugenol, the major compound of clove oil, and the essential oils (EOs) of Lippia alba and Aloysia triphylla are effective anesthetics for white shrimp (Litopenaeus vannamei) and can be used for short-term anesthesia and transport (Parodi et al. 2012). However, anesthesia studies in brachyuran decapods are still scarce.

Based on the evidences, our hypothesis is that use of essential oils can be a new approach to anesthesia of invertebrates in order to reduce or avoid the physiological stress during manipulation or invasive procedures. Thus, the aim of this study was to investigate the anesthetic efficiency of different natural products using the brachyuran crab, Neohelice granulata, as an experimental model.

\section{MATERIALS AND METHODS}

\section{ANIMALS}

Adult male $N$. granulata crabs $(n=250)(10.2 \pm$ $0.35 \mathrm{~g}$ ) were collected in salt marshes around Rio Grande city, Southern Brazil, and transported to a laboratory. The animals were acclimated for at least 15 days before the experiments. Individuals were 
kept in tanks, with free access to air at $20^{\circ} \mathrm{C}, 20$ ppm of salinity, 12L:12D photoperiod, and $6.5 \mathrm{mg} \mathrm{O}_{2}$. $\mathrm{L}^{-1}$. The crabs were fed ad libitum with ground beef three times a week until the day of the experiment.

Essential oil of the leaves of Melaleuca alternifolia (tea tree oil; TTO) was purchased from Química Delaware Ltda, Brazil, and eugenol (99\% purity) was purchased from Biodinâmica ${ }^{\mathrm{TM}}$, Ibiporá, PR, Brazil. Nanoencapsulated TTO was obtained from Inventiva ${ }^{\circledR}$ (Porto Alegre, Brazil), and terpinen-4-ol was obtained from SigmaAldrich Corporation (St. Louis, United States, purity $\geq 97 \%$ ). Menthol (99.5\% purity) was purchased from Vetec ${ }^{\circledR}$ (Rio de Janeiro, Brazil). Essential oils of Lippia alba (EOLA) and Aloysia triphylla (EOAT) were obtained from fresh plants cultivated at the campus of the Universidade Federal de Santa Maria, in the city of Frederico Westphalen, Southern Brazil. The oil extraction from the leaves of these plants was performed by steam distillation, in a Clevenger apparatus and stored at $-20^{\circ} \mathrm{C}$ until use. EOLA, EOAT, and TTO composition was analyzed by gas chromatography. It is important emphasize that $A$. triphylla and $L$. alba showed potent anesthetic effects for withe shrimp (L. vannamei), as demonstrated by Parodi et al. (2012), while the M. alternifolia essential oil and terpinen-4-ol demonstrated potential anesthetic effects to silver catfish (Rhamdia quelen) (Souza et al. 2018), which aroused our interest in the use of these essential oils as possible anesthetic to $N$. granulata.

Gas chromatography-mass spectrometry total ion chromatogram analysis was performed using an Agilent-6890 gas chromatograph coupled with an Agilent 5973 mass selective detector under the following conditions: HP-5MS column, 5\%-phenyl-95\%-methylsiloxane, $30 \mathrm{~m} \times 0.25 \mathrm{~mm}$ $\times 0.25 \mu \mathrm{m}$; EI-MS, $70 \mathrm{eV}$; operating conditions, split inlet $1: 100$, temperature program $40-260^{\circ} \mathrm{C}$, $40^{\circ} \mathrm{C}$ for $4 \mathrm{~min}$, ramp rate $4^{\circ} \mathrm{C} / \mathrm{min}$, carrier gas $\mathrm{He}$, flow rate $1 \mathrm{~mL} \mathrm{min-1,} \mathrm{injector} \mathrm{and} \mathrm{detector}$ temperature $220^{\circ} \mathrm{C}$, interface temperature $250^{\circ} \mathrm{C}$, Databank (NIST 2002).

The constituents of the EOs were identified by comparing their mass spectra with a mass spectral library (NIST 2002) and by comparison of the Kovats retention index with data in the literature (Adams 2001).

The principal compounds in EOAT were E-citral (42.30\%) and Z-citral (29.92\%), while linalool (55.25\%) was the most abundant compound for EOLA, and for TTO the majorities components were terpinen-4-ol (41.98\%), $\gamma$-terpinene (20.15\%), and $\alpha$-terpinene (9.85\%) (Parodi et al. 2012, Saccol et al. 2013, Baldissera et al. 2016).

\section{PREPARATION OF ANESTHETICS}

For immersion tests, EOs, eugenol, and menthol were previously dissolved in ethanol at a ratio of 1:10 (stock solution) before they were added to the water. For injection or gavage tests, eugenol and menthol were used after being dissolved in ethanol or diluted in physiological solution for crustaceans (Maciel et al. 2014). Terpinen-4-ol and nanoencapsulated TTO were used pure or diluted in physiological solution.

\section{ANESTHETIC TESTS}

Crabs were selected randomly for each experimental group ( $n=5)$, and each animal was used only once. We divided the anesthetic tests into two experiments. In the first experiment, EOs and natural compounds were tested. In the second experiment, as TTO was the only EO with an anesthetic effect (see results), we decided to investigate the use of the major isolated compound derived from TTO.

\section{EXPERIMENT 1}

For the immersion tests, crabs were transferred to aquaria containing $1 \mathrm{~L}$ of continuously aerated sea water (20 ppm) together with 300, 500, 1000, 2000, 3000,5000 , or $8000 \mu \mathrm{L} \mathrm{L}^{-1}$ of eugenol, EOLA, 
EOAT, and TTO, or 1500, 4000, and $10000 \mu \mathrm{L} \mathrm{L}^{-1}$ of menthol. Exposure to ethanol was also performed at the same concentration used for dilution of the highest EO concentrations.

Insulin syringes (BD Ultra-Fine ${ }^{\mathrm{TM}}$ ) were used for the injection tests with 25 or $50 \mu \mathrm{L}$ of EOs, eugenol, and menthol. Subsequently, these products were also tested diluted 10, 100, 1000, 10000 , or 100000 -fold in crustacean physiological solution. The needle was inserted through the arthrodial membrane between the carapace and the coxa of the swimming pereopod. Insulin syringes were inserted in the oral cavity for the gavage with $50 \mu \mathrm{L}$ of EOs (Figure 1).

The behavior of the crabs was observed to evaluate the time required for the induction of anesthesia, based on the procedure reported by
Gardner (1997) and Morgan et al. (2011), with some adaptations (Table I). Crabs were classified as in the stage of sedation when they demonstrated partial loss of equilibrium, but were still reactive to touch stimuli. Crabs were classified as in the stage of anesthesia when they demonstrated complete loss of equilibrium and were not reactive to stimuli. After induction, the crabs were transferred to an anesthetic-free aquarium to measure the anesthesia recovery time. Animals were considered recovered when normal equilibrium and reaction to external stimuli were observed.

\section{EXPERIMENT 2}

The anesthetic tests were performed as described in Experiment 1. Terpinen-4-ol and nanoencapsulated

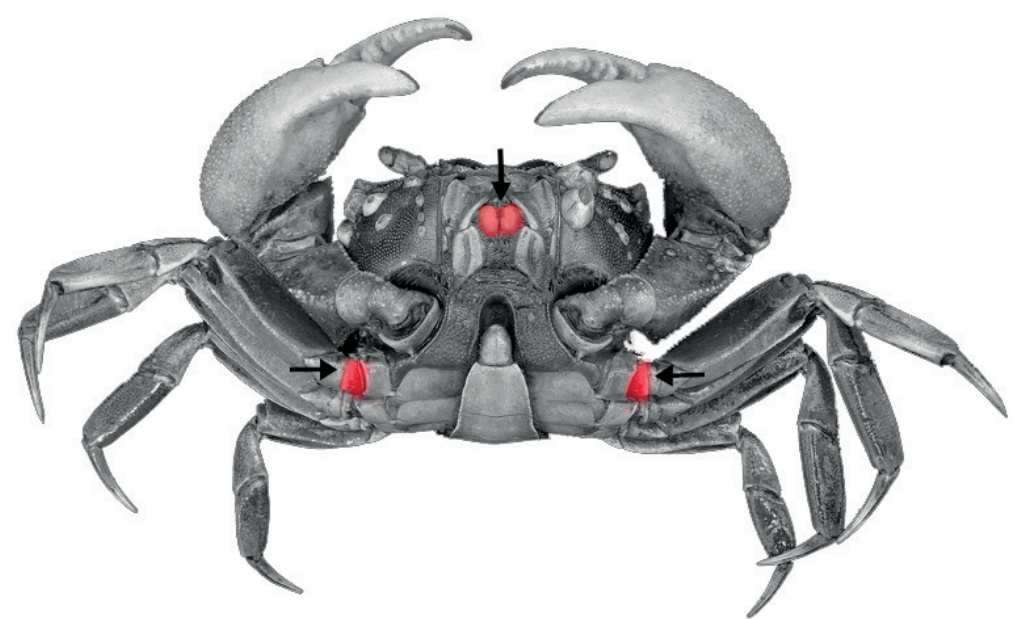

Figure 1 - Sites of injection (arrows) used in this study.

TABLE I

Evaluation of anesthetic stages for the crab Neohelice granulata.

\begin{tabular}{cc}
\hline Stages of anesthesia & Behavioral characteristic \\
\hline Sedation & Loss of righting reflex and defensive response \\
& Slow and occasional limb movement \\
& Relaxed abdominal flap and chelae \\
& Slow limb withdrawal when pressure applied with forceps \\
\hline Anesthesia & Loss of righting reflex and defensive response \\
& Complete limb immobility \\
& Relaxed abdominal flap and chelae \\
& Limb withdrawal absent when pressure applied with forceps \\
\hline Recovery & Return of defensive behavior or righting response, or both
\end{tabular}

Modified from Gardner (1997) and Morgan et al. (2011). 
TTO were used at concentrations of 300, 500, 1000, 2000, 3000, 5000, or $8000 \mu \mathrm{L} \mathrm{L}^{-1}$ for immersion tests. For the injection tests, nanoencapsulated TTO and terpinen-4-ol were used at doses of 20, 40, 60 $\mu \mathrm{L}$, or $10,20,30$, or $40 \mu \mathrm{L}$, respectively. In addition, they were also tested after diluting 10, 100, 1000, 10000 , or 100000 -fold in crustacean physiological solution for injection. Control experiments were performed using only nano blank.

\section{STATISTICAL ANALYSIS}

The results are presented as means \pm standard error of the mean (SEM). Since most data were homoscedastic, as evident with Levene's test, differences between groups were analyzed and detected using one-way analysis of variance
(ANOVA) followed by Tukey's test. The differences were considered to be statistically significant at $p<0.05$. All analyses were carried out using the software Statistica 7.0 (Stat Soft, Tulsa, OK).

\section{RESULTS}

Most products tested did not produce any anesthetic efficacy for $N$. granulata, irrespective of the application method. EOLA and EOAT, when injected or used in oral gavage, caused autotomy and/or death (up to $30 \mathrm{~min}$ ). However, TTO and eugenol produced anesthetic effects in the immersion test, but only at the highest concentration $\left(8000 \mu \mathrm{L} \mathrm{L}^{-1}\right)(p<0.05)$ (Table II). Anesthesia induction and recovery with TTO and eugenol were observed within 20-30 min.

TABLE II

Method of exposure, induction and recovery times (in seconds), and anesthetic effects of essential oils and compounds tested in Neohelice granulata.

\begin{tabular}{|c|c|c|c|c|c|}
\hline Substance & $\begin{array}{c}\text { Dose }(\mu \mathrm{L}) \text { or } \\
\text { concentration }\left(\mu \mathrm{L} \mathrm{L}^{-1}\right)^{*}\end{array}$ & Method & $\begin{array}{l}\text { Induction (s), } \\
\text { median } \\
\text { (minimum- } \\
\text { maximum) }\end{array}$ & $\begin{array}{l}\text { Recovery (s), } \\
\text { median } \\
\text { (minimum- } \\
\text { maximum) }\end{array}$ & $\begin{array}{c}\text { Anesthetic } \\
\text { effect }\end{array}$ \\
\hline \multirow[t]{4}{*}{ Eugenol } & up to 7000 & Immersion & $\mathrm{NE}$ & $\mathrm{NE}$ & None \\
\hline & 8000 & Immersion & $1440(1020-2460)$ & $1560(600-2820)$ & Light (1) / deep (4) \\
\hline & 25 and 50 & Injected & $\mathrm{NE}$ & $\mathrm{NE}$ & Autotomy $(60 \%) /$ death $(80 \%)$ \\
\hline & up to $100^{+}$ & Injected & $\mathrm{NE}$ & $\mathrm{NE}$ & None \\
\hline Menthol & 1500,4000, and 10000 & Immersion & $\mathrm{NE}$ & $\mathrm{NE}$ & None \\
\hline \multirow[t]{4}{*}{ EOLA } & up to 5000 & Immersion & $\mathrm{NE}$ & $\mathrm{NE}$ & None \\
\hline & 25 and 50 & Injected & $\mathrm{NE}$ & $\mathrm{NE}$ & Autotomy $(20 \%) /$ death $(100 \%)$ \\
\hline & 50 & Oral gavage & $900(480-1920)$ & - & Deep/death $(100 \%)$ \\
\hline & up to $100^{+}$ & Injected & $\mathrm{NE}$ & $\mathrm{NE}$ & None \\
\hline \multirow[t]{4}{*}{ EOAT } & up to 7000 & Immersion & $\mathrm{NE}$ & $\mathrm{NE}$ & None \\
\hline & 25 and 50 & Injected & $\mathrm{NE}$ & $\mathrm{NE}$ & Death \\
\hline & 50 & Oral gavage & $1080(600-2580)$ & - & Deep and death (100\%) \\
\hline & up to $100^{+}$ & Injected & $\mathrm{NE}$ & $\mathrm{NE}$ & None \\
\hline \multirow[t]{2}{*}{ TTO } & up to 7000 & Immersion & $\mathrm{NE}$ & $\mathrm{NE}$ & None \\
\hline & 8000 & Immersion & $761.28(360-926)$ & $1458(72-2580)$ & Deep \\
\hline \multirow[t]{2}{*}{ Terpinen-4-ol } & up to 8000 & Immersion & $\mathrm{NE}$ & $\mathrm{NE}$ & None \\
\hline & up to $100^{+}$ & Injected & $\mathrm{NE}$ & $\mathrm{NE}$ & None \\
\hline \multirow[t]{2}{*}{ Nanoencapsulated TTO } & up to 8000 & Immersion & $\mathrm{NE}$ & $\mathrm{NE}$ & None \\
\hline & up to $100^{+}$ & Injected & $\mathrm{NE}$ & $\mathrm{NE}$ & None \\
\hline
\end{tabular}

EOLA - essential oil of Lippia alba; EOAT - essential oil of Aloysia triphylla; TTO - essential oil of Melaleuca alternifolia ${ }^{*}$ Dose: used for injection or oral gavage; concentration used for immersion. NE - Not effective. ${ }^{+}$Diluted in physiological solution at $10 \mathrm{X}$, 100X, 10000X, and 100000X. 
Induction of anesthesia was obtained with terpinen-4-ol and nanoencapsulated TTO (Figure 2). A faster anesthetic effect was observed with injection of 40 and $60 \mu \mathrm{L}$ nanoencapsulated TTO, and 30 and $40 \mu \mathrm{L}$ terpinen-4-ol (both without any dilution in physiological solution), with a maximum time of $407.4 \mathrm{~s}$ for anesthesia induction; however, injection of $20 \mu \mathrm{L}$ terpinen-4-ol produced longer induction time (2361.2 s). Anesthetic recovery for crabs anesthetized with nanocapsulated TTO was
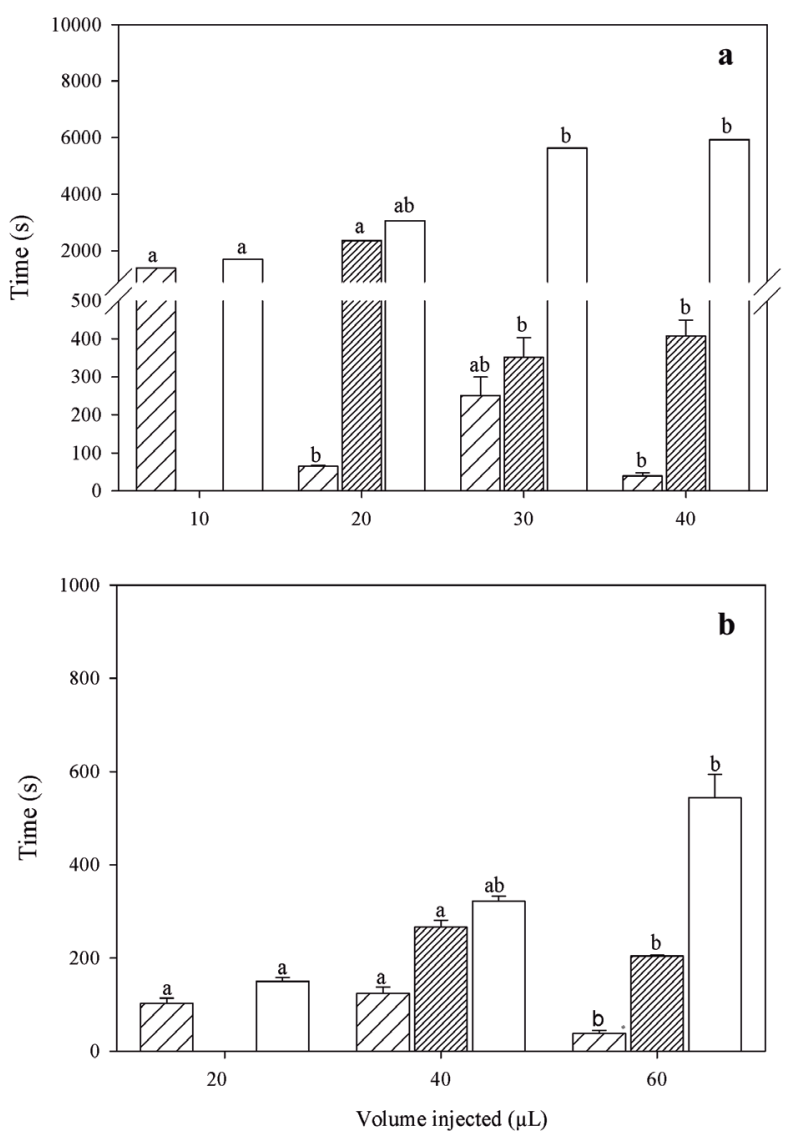

$$
\nvdash \text { Sedation }
$$

Figure 2 - Induction and recovery times of terpinen-4-ol (a) and nanoencapsulated TTO (b) injected in Neohelice granulata. Stages of induction were observed according to Gardner (1997) and Morgan et al. (2011). Maximum observation time for induction and recovery was $30 \mathrm{~min}$. Data are presented as mean \pm SEM $(n=5)$. Different letters indicate significant differences between concentrations, for the same stage $(p<0.05)$. rapid, with a maximum of approximately $540 \mathrm{~s}$. However, the recovery time after treatment with terpinen-4-ol was lengthier, exceeding $30 \mathrm{~min}$.

\section{DISCUSSION}

The present study is the first to report anesthetic activity in vivo for crabs using nanotechnological preparations, and demonstrated a low susceptibility of $N$. granulata to anesthesia by immersion with the tested EOs. Only TTO and eugenol (compound derived from clove oil) produced anesthetic effects by immersion, but both had long induction and recovery times. Eugenol produced $60 \%$ anesthetic efficacy in $N$. granulata up to $1800 \mathrm{~s}$, and the recovery time was, on average, $1560 \mathrm{~s}$ at the highest tested concentration $\left(8000 \mathrm{~mL} \mathrm{~L}^{-1}\right)$, similar to observed using eugenol administered by immersion at $20000 \mu \mathrm{L} \mathrm{L}^{-1}$ in the crab Eriocheir sinensis, but only $20 \%$ of the animals were anesthetized (Hajek et al. 2009). However, exposure of the three-spot swimming crab, Portunus sanguinolentus, to clove oil added to sea water $\left(200 \mu \mathrm{L} \mathrm{L}^{-1}\right)$ produced a faster induction time, approximately $800 \mathrm{~s}$, but recovery was slower, about $2460 \mathrm{~s}$ (Premarathna et al. 2016). These authors also suggested that clove oil (which is widely available and low cost), although it causes slow recovery, can be used as an anesthetic for crabs when prolonged anesthesia is required. Eugenol is an efficient anesthetic for white shrimp (L. vannamei); where 175 and $200 \mu \mathrm{L} \mathrm{L}^{-1}$ of eugenol was shown to induce deep anesthesia in larvae and sub-adults, respectively, within a maximum time of $500 \mathrm{~s}$ (Parodi et al. 2012), but is not efficient for $N$. granulata. Interestingly, Morgan et al. (2001) demonstrated large differences in concentrations of eugenol used to induce anesthesia in three crayfish species (Cancer magister, Hemigrapsus oregonensis, and Pugettia producta), suggesting that differences in anesthetic efficiency could be because of the specificity of chemical receptors (Saydmohammed and Pal 2009), which could also 
explain the low anesthetic efficacy of eugenol for $N$. granulata. Thus, the eugenol no can be considered an effective anesthetic agent for $N$. granulata via oral gavage, injected or by immersion.

Intravascular administration of EOs and eugenol was not effective and, in some cases, provoked autotomy and/or death. Although the exact cause of the crab mortalities in the present study was not determined, Minter et al. (2013) related to limb autotomization occurs in an attempt to prevent excessive loss of hemolymph. The hemolymph, in the same way as the blood in vertebrates, is an aqueous medium and therefore is immiscible with most essential oils. According to Turner et al. (2011), some oily substances may induce hemolysis when they are introduced intravenously. Despite their anesthetic ineffectiveness for N. granulata, EOs and eugenol injected at $50 \mu \mathrm{L}$ may be suitable agents for euthanasia.

Silva et al. (2013) verified the sedative properties of an immersion bath of terpinen-4-ol at 3 and $10 \mathrm{mg} \mathrm{L}^{-1}$, in silver catfish ( $R$. quelen). The median induction times observed for terpinen-4ol and nanoencapsulated TTO were comparable to those seen with injectable synthetic anesthetics in crustaceans, such as ketamine, xylazine, procaine, lidocaine, and alfaxalone (Brown et al. 1996, Gardner, 1997, Quesada et al. 2011, Minter et al. 2013). It appeared that the injection of terpinen4-ol and nanoencapsulated TTO did not cause large physiological alterations in the crabs, since there were no observed changes in autotomy or behavior, and no mortality was observed during or after recovery. Crustaceans respond differently to anesthesia than fish, possibly because their synaptic receptor sites are not affected by certain anesthetics (Ross and Ross 2008). In addition, much higher concentrations are required to anesthetize crustaceans than fish (Cunha et al. 2010a, b, Parodi et al. 2012, 2014). TTO at $200 \mu \mathrm{L} \mathrm{L}^{-1}$ is enough to anesthetize common carp (Cyprinus carpio) (Hajek 2011) and gilthead seabream (Sparus aurata) (Golomazou et al. 2016), while $8000 \mu \mathrm{L}$ $\mathrm{L}^{-1}$ of TTO was required to anesthetize $100 \%$ of $N$. granulata, which makes the use of TTO practically inviable due the volume used and elevated cost of procedure. In contrary, injections of nondiluted nanoencapsulated TTO and terpinen-4-ol provided rapid and reliable anesthesia induction in $N$. granulata at 40 and $60 \mu \mathrm{L}$, and 30 and $40 \mu \mathrm{L}$, respectively.

Based on these findings, it can be confirmed that $N$. granulata is neurosensitive to water soluble EO constituents, such as terpinen-4-ol (Hart et al. 2000) and some nanoencapsulated EOs (Assis et al. 2012). Although Abbott (1970) demonstrated the absence of a hemolymph-brain barrier in crabs (Carcinus maenas), it is possible to speculate that there exists a more rigid barrier, which hinders the passage of some water insoluble molecules. The study conducted by Baldissera et al. (2017) demonstrated that sesquiterpene nerolidol did not exhibit anti-parasitic effects in mice experimentally infected with Trypanosoma evansi, but when this compound was nanoencapsulated, it crossed the blood-brain barrier (BBB) and had 100\% antiparasitic efficacy. Thus, our results indicate that the nanoencapsulation of TTO allowed the passage of terpinen-4-ol through the more rigid barrier of crabs, and consequently, induced anesthesia. On the contrary, Maldonado et al. (1997) pointed out that the absence of an endothelial hemolymphbrain barrier in crabs would be responsible for the increased action of compounds administered systemically. However, only water-soluble compounds, such as cloheximide actinomycin-D, angiotensin II, enkephalin, and serotonin were tested. Therefore, future studies should investigate the existence of a hemolymph-brain barrier in $N$. granulata using the Evans Blue dye.

A previous study conducted by Melo et al. (2010) showed that nanoencapsulated benzocaine presented with increased solubility, thereby improving absorption and consequently 
potentiating its in vitro action. Consistent with this, Alonso (2004) and De Jong et al. (2008) demonstrated that nanotechnology can facilitate the transfer of drugs through biological barriers through the reduction on size in the nanometric scale. Also, study conducted by Mistry et al. (2015) demonstrated that nanostructures with 20-200 nm presents a better capacity to cross the $\mathrm{BBB}$, and the nanoencapsulated TTO used in this present study presents $150.2 \mathrm{~nm}$, which also may explain the success of anesthesia with nanoencapsulated TTO.

In conclusion, most anesthetic protocols investigated in this study were not suitable for $N$. granulata, such as A. triphylla, L. alba and TTO essential oils, and the eugenol. Anesthesia by immersion appears to be inadequate, and injection of the above cited treatments are inappropriate and causes autotomy and/or death. As an alternative, we propose the use of nanoencapsulated EOs and isolated compounds, as TTO nanoencapsulated and terpinen-4-ol. We recommend the use of 20 and $40 \mu \mathrm{L}$ of terpinen-4-ol and nanoencapsulated TTO, respectively, for short duration anesthesia of $N$. granulata. In summary, TTO nanoencapsulated and terpinen-4-ol can be considered effective as anesthetic to $N$. granulata for use to reduce or avoid stress during manipulation. In addition, future studies must be conducted to evaluate the effects of isolated compounds on the physiology of N. granulata.

\section{ACKNOWLEDGMENTS}

We thank A.L. Escarrone and B.D.P. Righi for initially helping us with the manipulation of crabs and preliminary tests. B. Baldisserotto, B.M. Heinzmann and B.O. Caron received Conselho Nacional de Desenvolvimento Científico e Tecnológico (CNPq) research fellowships, and C.F. Souza and M.D. Baldissera received Coordenação de Aperfeiçoamento de Pessoal de Nível Superior (CAPES) PhD fellowships.

\section{REFERENCES}

ABBOTT J. 1970. Absence of Blood-Brain Barrier in a Crustacean, Carcinus maenas L. Nature 225: 291-293.

ADAMS RP. 2001. Identification of Essential Oil Components by Gas Chromatography/ Quadruple Mass Spectroscopy. Allured Publishing Corporation, Illinois, $455 \mathrm{p}$.

ALONSO MJ. 2004. Nanomedicines for overcoming biological barriers. Biomed Pharmacother 58: 168-172.

ASSIS LM, ZAVAREZE ER, PRENTICE-HERNÁNDEZ C AND SOUZA-SOARES LA. 2012. Characteristics of nanoparticles and their potential applications in foods. Braz J Food Technol 15: 99-109.

AVMA - AMERICAN VETERINARY MEDICAL ASSOCIATION. 2007. 'AVMA guidelines on euthanasia'. Available at: http://www.avma.org/issues/animal_welfare/ euthanasia.pdf. Aquaculture 416/417: 244-254.

BALDISSERA MD, GRANDO TH, SOUZA CF, GRESSLER LT, STEFANI LM, SILVA AS AND MONTEIRO SG. 2016. In vitro and in vivo action of terpinen-4-ol, $\gamma$-terpinene, and $\alpha$-terpinene against Trypanosoma evansi. Exp Parasitol 162: 43-48.

BALDISSERA MD, SOUZA CF, BOLIGON AA, GRANDO TH, DE SÁ MF, DA SILVA AS, STEFANI LM, BALDISSEROTTO B AND MONTEIRO SG. 2017. Solving the challenge of the blood-brain barrier to treat infections caused by Trypanosoma evansi: Evaluation of nerolidol-loaded nanospheres in mice. Parasitology 44: 1543-1550.

BARR S, LAMING PR, DICK JTA AND ELWOOD RW. 2008. Nociception or pain in a decapod crustacean? ¡Anim Behav 75: 745-751.

BOWNIK A. 2015. Clove essential oil from Eugenia caryophyllus induces anesthesia, alters swimming performance, heart functioning and decreases survival rate during recovery of Daphnia magna. Turk J Fish Aquat Sci 15: 157-166.

BROWN PB, WHITE MR, CHAILLE J, RUSSELL M AND OSETO C. 1996. Evaluation of three anesthetic agents for crayfish (Orconectes virilis). J Shellfish Res 15: 433-435.

COOPER JE. 2011. Anesthesia, analgesia, and euthanasia of invertebrates. ILAR J 52: 196-204.

CUNHA MA, BARROS FMC, GARCIA LO, VEECK APL, HEINZMANN BM, LORO VL, EMANUELLI T AND BALDISSEROTTO B. 2010a. Essential oil of Lippia alba: a new anesthetic for silver catfish, Rhamdia quelen. Aquaculture 306: 403-406.

CUNHA MA, GARCIA LO, LORO VL, FONSECA MB, EMANUELLI T, VEECK APL, COPATTI CE AND BALDISSEROTTO B. 2010b. Anesthesia of silver catfish with eugenol: time of induction, cortisol response and sensory analysis of fillet. Cienc Rur 40: 2107-2114. 
DE JONG WH AND BORM PJA. 2008. Drug delivery and nanoparticles: Applications and hazards (Review). Int J Nanotechnol Nanomed 3: 133-149.

ELWOOD RW AND APPEL M. 2009. Pain experience in hermit crabs? Anim Behav 77: 1243-1246.

FERRARO EA AND PRESSACCO L. 1996. Anesthetic procedures for crustaceans. An assessment of isobutanol and xylazine as general anaesthetics for Squilla mantis (Stomapoda). Mem Biol Mar Oceanogr 12: 471-475.

FREGIN T AND BICKMEYER U. 2016. Electrophysiological investigation of different methods of anesthesia in lobster and crayfish. PLoS ONE 11: e0162894.

GARDNER C. 1997. Options for humanely immobilizing and killing crabs. J Shellfish Res 16: 219-224.

GOLOMAZOU E, MALANDRAKIS EE, KAVOURAS M, KARATZINOS T, MILIOU H, EXADACTYLOS A AND PANAGIOTAKI P. 2016. Anaesthetic and genotoxic effect of medicinal plant extracts in gilthead seabream (Sparus aurata L.). Aquaculture 464: 673-682.

GONÇALVES RA, ARAGÃO C, FRIAS PA AND SYKES AV. 2012. The use of different anaesthetics as welfare promoters during short-term human manipulation of European cuttlefish (Sepia officinalis) juveniles. Aquaculture 370/371: 130-135.

GRIFFITHS SP. 2000. The use of clove oil as an anaesthetic and method for sampling intertidal rockpool fishes. J Fish Biol 57: 1453-64.

GUNKEL CI AND LEWBART GA. 2007. Invertebrates. In: West GD, Heard DJ and Caulkett NA (Eds), Zoo \& Wildlife Immobilization and Anesthesia, Blackwell Publishing, Ames, Iowa, p. 147-158.

HAJEK GJ. 2011. The anaesthetic-like effect of tea tree oil in common carp Cyprinus carpio L. Aquacult Res 42: 296-300.

HAJEK GJ, CHOCZEWSKI M, DZIAMAN R AND KŁYSZEJKO B. 2009. Evaluation of immobilizing methods for the Chinese mitten crab, Eriocheir sinensis (Milne-Edwards). Electr J Pol Agric Univ 12: 18.

HART PH, BRAND C, CARSON CF, RILEY TV, PRAGER RH AND FINLAY-JONES JJ. 2000. Terpinen-4-ol, the main component of the essential oil of Melaleuca alternifolia (tea tree oil), suppresses inflammatory mediator production by activated human monocytes. Inflamm Res 49: 619-626.

HERNÁNDEZ SE, SERNIA C AND BRAD AJ. 2012. The effect of three anaesthetic protocols on the stress response in cane toads (Rhinella marina). Vet Anaesth Analg 239: 584-590.

KEENE JL, NOAKES DLG, MOCCIA RD AND SOTO CG. 1998. The efficacy of clove oil as an anaesthetic for rainbow trout, Oncorhynchus mykiss (Walbaum). Aquacult Res 29: 89-101.

MACIEL FE, GEIHS MA, CRUZ BP, VARGAS MA, ALLODI S, MARINS LF AND NERY LEM. 2014. Melatonin as a signaling molecule for metabolism regulation in response to hypoxia in the crab Neohelice granulata. Int J Mol Sci 15: 22405-22420.

MALDONADO H, ROMANO A AND TOMSIC D. 1997. Long-term habituation (LTH) in the crab Chasmagnathus: a model for behavioral and mechanistic studies of memory. Braz J Med Biol Res 30: 813-826.

MARDER E. 2011. Variability, compensation, and modulation in neurons and circuits. Proc Natl Acad Sci USA 108: 15542-15548.

MELO NFS, GRILLO R, ROSA AH, FRACETO LF, DIAS FILHO NL, DE PAULA E AND ARAÚJO DR. 2010. Development and characterization of poli (L-lactide) nanocapsules containing benzocaine. Quim Nova 33: 65-69.

MINTER LJ, HARMS CA, ARCHIBALD KE, BROADHURST H, BAILEY KM, CHRISTIANSEN EF, LEWBART GA AND POSNER LP. 2013. Efficacy of alfaxalone for intravascular anesthesia and euthanasia in blue crabs (Callinectes sapidus). J Zoo Wildl Med 44: 694-699.

MISTRY A, STOLNICK S AND ILLUM L. 2015. Noseto-brain delivery: investigation of the transport of nanoparticles with different surface characteristics and size in excised porcine olfactory epithelium. Mol Pharm 12: $2755-2766$.

MORGAN J, CARGILL C AND GROOT E. 2001. The efficacy of clove oil as an anesthetic for decapod crustaceans. Bull Aquacult Assoc Can 101: 27-31.

NIST/EPA/NIH. 2002. Mass spectral library and search/ analysis programs. J Wiley \& Sons, Hoboken, NJ.

PARODI TV ET AL. 2012. The anesthetic efficacy of eugenol and the essential oils of Lippia alba and Aloysia triphylla in post-larvae and subadults of Litopenaeus vannamei (Crustacea, Penaeidae). Comp Biochem Physiol C 155: 462-468.

PARODI TV, CUNHA MA, BECKER AG, ZEPPENFELD CC, MARTINS DI, KOAKOSKI G, BARCELLOS LG, HEINZMANN BM AND BALDISSEROTTO B. 2014. Anesthetic activity of Aloysia triphylla and effectiveness in reducing stress during transport of albine and grey strains of silver catfish, Rhamdia quelen. Fish Physiol Biochem 40: 323-34.

PREMARATHNA AD, PATHIRANA I, JAYANTHA RAJAPAKSE RPV AND PATHIRANA E. 2016. Evaluation of efficacy of selected anesthetic agents on blood-spotted crab (Portunus sanguinolentus). J Shellfish Res 35: 237-240.

QUESADA RJ, SMITH CD AND HEARD DJ. 2011. Evaluation of parenteral drugs for anesthesia in the blue crab (Callinectes sapidus). J Zoo Wildl Med 42: 295-299.

ROSS LG AND ROSS B. 2008. Anaesthetic and sedative techniques for aquatic animals. $3^{\text {rd }}$ ed., Oxford, Blackwell, p. 236. 
SACCOL EMH ET AL. 2013. Addition of Lippia alba (Mill) N.E. Brown essential oil to the diet of the silver catfish: analysis of growth, metabolic and blood parameters and the antioxidant response. Aquaculture 416/417: 244-254.

SAYDMOHAMMED M AND PAL AK. 2009. Anesthetic effect of eugenol and menthol on handling stress in Macrobrachium rosenbergii. Aquaculture 298: 162-167.

SEOL DW, LEE J, IM SY AND PARK IS. 2007. Clove oil as an anaesthetic for common octopus (Octopus minor, Sasaki). Aquacult Res 38: 45-49.

SILVA LL, GARLET QI, BENOVIT SC, DOLCI G, MALLMANN CA, BÜRGER ME, BALDISSEROTTO B, LONGHI SJ AND HEINZMANN BM. 2013. Sedative and anesthetic activities of the essential oils of Hyptis mutabilis (Rich.) Briq. and their isolated components in silver catfish (Rhamdia quelen). Braz J Med Biol Res 46: 771-779.

SOUZA CF, BALDISSERA MD, SILVA LL, GEIHS M AND BALDISSEROTTO B. 2018. Is monoterpene terpinen4-ol the compound responsible for the anesthetic and antioxidant activity of Melaleuca alternifolia essential oil (tea tree oil) in silver catfish? Aquaculture 486: 217-223.

TANG LS, TAYLOR AL, RINBERG A AND MARDER E. 2012. Robustness of a rhythmic circuit to short- and longterm temperature changes. J Neurosci 32: 10075-10085.

TURNER PV, BRABB T, PEKOW C AND VASBINDER MA. 2011. Administration of substances to laboratory animals: Routes of administration and factors to consider. J Am Assoc Lab Anim Sci 50: 600-613.

YUE S. 2008. The welfare of crustaceans at slaughter, Humane Society of the United States 1, $10 \mathrm{p}$. 